\title{
Problem Based Learning Model using Exe-Learning for Mechanical Waves
}

\author{
$1^{\text {st }}$ Fathiah Alatas ${ }^{1}, 2^{\text {nd }}$ Mia Oktaviani ${ }^{1}$ \\ \{fathiah.alatas@uinjkt.ac.id¹, mia.oktaviani@mhs.uinjkt.ac.id ${ }^{1}$ \} \\ UIN Syarif Hidayatullah, Jakarta, Indonesia ${ }^{1}$
}

\begin{abstract}
Mechanical Wave is considered as an abstract materials in physics, thereby requires support from learning media for contextual problems presentation. The present research applies the exe-learning in the model of problem based learning. Such eXe shall encourages to troubleshooted, analyzed and finding the solution for authentic problem as well as scientific attitude that expected to emerge as a result of their learning process. The research method used was a quasi- experiment design with nonequivalent control group. The results showed that using problem based learning model-assisted exe-learning able to improve student's learning outcomes as well as promoting the scientific attitude of medium and higher level. Therefore, this research may serve as an alternative for learning physics thus becoming more effective and efficient.
\end{abstract}

Keywords: Problem Based Learning Model, Exe-Learning, Mechanical Waves

\section{Introduction}

Mechanical Waves is one of the abstract concepts of physics [1] which is considered difficult by students in term of cognitive aspects [2], which lead to poor comprehension of such concept by the student [3]. The problems experienced by the students i.e. difficulty in understanding the basic concept of mechanical waves. For example, students are frequently having misconception about the direction and the wave speed [4]. The equation to determine the waves speed is as follows:

$$
\mathrm{v}=\lambda . \mathrm{f} .
$$

Where $f$ is the wave frequency and $\lambda$ is the wavelength [5]. To determine the refraction index, $\mathrm{n}$ is a relative index of two medium inter alia as shown in the following equation:

$$
n=\frac{\left|U_{i}\right|}{\left|U_{t}\right|}
$$

Where $\left|\mathrm{U}_{\mathrm{i}}\right|$ is the initial speed in medium 1, and $\mathrm{Ut}$ is the final speed (2 medium). This shows that $\mathrm{n}$ is the refraction index of the two mediums (bending) of the coming wave [6]. Interference is a fusion of coherent two waves. To determine the wave interference using the formula of the Pythagorean theorem:

$$
\Delta D=d \sin \theta
$$


Where $\Delta D$ is the distance between two sources coherented with the site where the interference pattern is observed, $d$ is the distance between two coherent sources and $\theta$ is the angle. Compare wave diffraction by a slit width of wavelength [7].

As mentioned previously regarding poor conseptual comprehension rooting from less suitable model and learning method applied for the intended topic [8]. The student's misconception is that the wave transfers the material while in fact the wave only transfers energy [4]. One of the learning models able to minimize miconception of the mechanical wave is a model of problem based learning (PBL) [9] [10]. PBL model is a learning model which involves the contextual issues, generating students with the ability to apply the skills of problem solving in real life, and provide an opportunity to engage students in an exploration of problem solving [11]. PBL model may improve communication between students from interaction with the rest of the Group [12], enhance cooperation in group activities, student understanding of the concepts, engage in working independently, and participate in the discussion [13]. Discussions with classmates to build communication between mates in problem solving [14], by applying the knowledge [15] .

Problem based learning model is composed of five stages of learning consisting; students focus on the issue, organized the students learning, individual and group investigations, developing and presenting the work, analyzing and evaluating the process of problem solving [16]. The model of problem based learning encourages students to be able to interpret, collect new information, identify solutions and methods, solve problems, collaborate, discuss, and compare the idea to produce a conclusion [17] [18], as well developing a scientific attitude in physics [19]. In addition to improve the learning outcomes, the psychomotoric also improve [20]. The scientific attitude is the attitude toward science of how the students feel and think about science [21]. Scientific attitude is related to student learning outcomes. Kaptan and Korkmaz have conducted research on the influence of PBL effect on the scientific attitude of students [22].

PBL model encourage students to understand concepts through discussion, students collaboration, social interaction supported by computer device [23]. Computer devices is one of the tools to support the student's learning process [24], and try to understand some concepts that are abstract [25]. Learning media used is the exe learning media [23]. It's easy to use without extensive programming language [26].

Based on the above explanation, the study objective is to apply PBL model by using the eXe-Learning in learning the characteristics of mechanical wave, and to determine its effect to the learning outcomes and scientific attitude of the students. The attitude observed is attitude after learning, by observing the academic ability of students. Academic ability is the individual ability that allows them to give a proper response on stimulus received [27], processing information and improving the ability to complete tasks [28].

\section{Methodology}

The population in this study is the entire students of XI MAN 3 Tangerang. The sample in the study is grade XI IPA 2 as a experimental group and Class of XI IPA 3 as the control group. Academic ability of the students is grouped into 3 groups including students who possess higher academic ability as much as 7 students, There are 20 students who have middle academic ability, and 8 students who have poor capability either in experimental or 
control group. Experimental group were taught with the model of problem based learning assisted exe-learning, while the control group is taught using the conventional model.

The research method used was quasi experiment method with the nonequivalent control group design research design [29][30]. Sampling techniques is the purposive sampling techniques [31] [32].

Da sampling in this studwas conducted using the test and non-test. Testing method was utilized to measure learning outcomes in the form of pre-test and post-test. The instruments utilized are leartning outcomes test and scientific attitute quotioner. Test results obtained subsequently analyzed using a test N-Gain equation 1 [33].

$$
N-\text { Gain }=\frac{\text { posttest }- \text { pretest }}{100-\text { pretest }}
$$

Determination of $\mathrm{N}-\mathrm{Gain}$ value criteria is $0<\mathrm{G}<0,3$ low Category, $0.3 \leq \mathrm{G}<0.7$ medium Category, dan $0.7<\mathrm{G}$ High Category [34]. Prerequisite test utilized the test of normality (Kolmogorov-Smornov test) and homogenity test (test Levene). Test hypotheses utilized the parametric tests was Test $\mathrm{T}$ with significance level $5 \%(\alpha=0.05)$.

The scientific attitude data were calculated using formula as follows: [35]

$$
\text { Percentage }=\frac{\text { score }}{\text { maximum score }} \times 100 \%
$$

Determination of scientific attitude criteria is very good $(86 \%-100 \%)$, good $(76 \%-85 \%)$, sufficient $(60 \%-75 \%)$, poor $(55 \%-59 \%)$ and very poor $(\leq 54 \%)[36]$.

\section{Result and discussion}

\subsection{Learning Outcomes}

Before treatment, we firstly conducted the pre-test to define the experiment and controls. Pre-test result was analyzed with Normality test of Kolmogorov-Shapiro Wilk as summarized in Table I below:

\begin{tabular}{|c|c|c|c|c|}
\hline \multirow{2}{*}{$\begin{array}{l}\text { Academic } \\
\text { Ability } \\
\text { Group }\end{array}$} & \multicolumn{2}{|c|}{$\begin{array}{l}\text { Experiment } \\
\text { Group }\end{array}$} & \multicolumn{2}{|c|}{ Control Group } \\
\hline & $\begin{array}{l}\text { Signifi } \\
\text { cation }\end{array}$ & Description & $\begin{array}{l}\text { Signifi } \\
\text { cation }\end{array}$ & $\begin{array}{l}\text { Descriptio } \\
\mathrm{n}\end{array}$ \\
\hline Low & 0.200 & Normal & 0.200 & Normal \\
\hline Middle & 0.117 & Normal & 0.023 & $\begin{array}{l}\text { Not } \\
\text { Normal }\end{array}$ \\
\hline High & 0.030 & Not Normal & 0.200 & Normal \\
\hline
\end{tabular}

Tabel 1. Pre-test normality test

Table I shows the results of normality test in pre-test. In, experimental group of poor and middle academic ability the data are normal, while the higher academic ability group has abnormal data. The academic control group which has normal data: poor and high academic ability.

Post-test results in analysis with test Kolmogorov-Shapiro Wilk normality on table II: 
Tabel 2. Posttest normality test

\begin{tabular}{|l|l|l|l|l|}
\hline \multirow{2}{*}{$\begin{array}{l}\text { Academic } \\
\text { Ability } \\
\text { Group }\end{array}$} & \multicolumn{2}{|c|}{ Experiment Group } & \multicolumn{2}{c|}{ Control Group } \\
\cline { 2 - 5 } & $\begin{array}{l}\text { Significati } \\
\text { on }\end{array}$ & $\begin{array}{l}\text { Descriptio } \\
\mathrm{n}\end{array}$ & Signification & Description \\
\hline Low & 0.200 & Normal & 0.200 & Normal \\
\hline Middle & 0.026 & $\begin{array}{l}\text { Not } \\
\text { Normal }\end{array}$ & 0.200 & Normal \\
\hline High & 0.200 & Normal & 0.200 & Normal \\
\hline
\end{tabular}

Table II shows the results of the post-test normality test in the experimental group and the control group. In the normality data, experimental group has normal data for low and high academic skill. Meanwhile all the data in control group is normal. the pre-test and post-test data were subsequently tested for their homogeneity to determine whether data is homogenous or heterogeneous. Homogeneity was tested using the Levene test using SPSS 21 and the result is summarized in the following Table III:

Tabel 3. Pre-test and post-test homogeneity test

\begin{tabular}{|l|l|l|l|l|}
\hline \multirow{2}{*}{$\begin{array}{l}\text { Academic } \\
\text { Ability } \\
\text { Group }\end{array}$} & \multicolumn{3}{|c|}{ Experiment Group and Control Group } \\
\cline { 2 - 5 } & $\begin{array}{l}\text { Pretest } \\
\text { Significat }\end{array}$ & $\begin{array}{l}\text { Descriptio } \\
\text { n }\end{array}$ & $\begin{array}{l}\text { Significat } \\
\text { ion }\end{array}$ & Description \\
\hline Low & 0.114 & Homogen & 0.420 & Homogen \\
\hline Middle & 0.547 & Homogen & 0.563 & Homogen \\
\hline High & 0.155 & Homogen & 0.119 & Homogen \\
\hline
\end{tabular}

Table III shows the results homogeneity test upon pre-test and post-test. It is shown that the experiment group and the control group obtained a homogeneous data in every level of academic ability of students. Pre-test and post-test data are re-tested with hypothesis test to determine the effects of the treatments. Hypothesis test results is summarized in the table IV below:

Tabel 4. Pre-test and post-test hypothesis test

\begin{tabular}{|c|c|c|c|c|}
\hline \multirow{2}{*}{ KKA } & \multicolumn{2}{|c|}{ Pretest } & \multicolumn{2}{c|}{ Posttest } \\
\cline { 2 - 5 } & Signification & Description & Signification & Description \\
\hline Low & 0.468 & $\mathrm{H}_{1}$ rejected & 0.189 & $\mathrm{H}_{1}$ rejected \\
\hline $\begin{array}{c}\text { Middl } \\
\text { e }\end{array}$ & 0.494 & $\mathrm{H}_{1}$ rejected & 0.000 & $\mathrm{H}_{1}$ accepted \\
\hline High & 0.115 & $\mathrm{H}_{1}$ rejected & 0.008 & $\mathrm{H}_{1}$ accepted \\
\hline
\end{tabular}

Table IV above shows that the use of the model of problem- based learning assisted exe learning may improve learning outcomes of students on academic ability groups, and higher academic ability. Students who learn to use the problem-based learning model is expected to connect the personal understanding of any of the information with previous experience, selfreliant and able to make decision on subject of learning to cultivate the motivation [37]. Exe learning media creates more flexible learning structure, easy, and can be updated. Exe learning media may have an effect on students' cognitive ability and the ability of the creative thinking 
[28]. Model of problem-based learning assisted exe-learning may improve student learning outcomes [38]. This is in accordance with the results of N-Gain of the learning outcomes. The results of the value $\mathrm{N}-$ Gain student learning results is shown in table V below:

Tabel 5. N-gain student learning outcomes

\begin{tabular}{|l|l|l|l|l|}
\hline \multirow{2}{*}{$\begin{array}{c}\text { Academic } \\
\text { Ability Group }\end{array}$} & \multicolumn{2}{c|}{ Experiment } & \multicolumn{2}{c|}{ Control } \\
\cline { 2 - 5 } & N-Gain & Category & N-Gain & Category \\
\hline Low & 0.55 & Middle & 0.43 & Middle \\
\hline Middle & 0.65 & Middle & 0.52 & Middle \\
\hline High & 0.73 & High & 0.54 & Middle \\
\hline
\end{tabular}

Table $\mathrm{V}$ above indicates that the experimental group has a value of N-Gains higher than that of control group, in both of the student's academic ability group, poor, middle academic ability, as well as a group of high academic ability. Problem- based learning may improve student learning outcomes [37]. Problem-based learning is developed to assist students to improve the student's thinking ability, problem-solving ability, and intellectual skills; connecting experience acquired through various situations, real or simulated situations; and become an independent learner [23].

Tabel 5. Scientific attitude of students

\begin{tabular}{|c|c|c|c|c|c|c|c|}
\hline \multirow[t]{2}{*}{ No } & \multirow{2}{*}{$\begin{array}{l}\text { Scientific } \\
\text { attitude of } \\
\text { Students }\end{array}$} & \multicolumn{2}{|c|}{$\begin{array}{c}\text { Low Academic } \\
\text { Ability }\end{array}$} & \multicolumn{2}{|c|}{$\begin{array}{c}\text { Middle Academic } \\
\text { Ability }\end{array}$} & \multicolumn{2}{|c|}{$\begin{array}{c}\text { High Academic } \\
\text { Ability }\end{array}$} \\
\hline & & $\%$ & Conclusion & $\%$ & Conclusion & $\%$ & $\begin{array}{c}\text { Conclusio } \\
\mathrm{n}\end{array}$ \\
\hline 1 & Inquisitive & 77.68 & Good & $\begin{array}{c}85.3 \\
1\end{array}$ & Good & 89.28 & Very Good \\
\hline 2 & respect to data & 81.25 & Good & 85 & Good & 86.61 & Very Good \\
\hline 3 & critical thinking & 80.36 & Good & 83.33 & Good & 89.28 & Very Good \\
\hline 4 & $\begin{array}{l}\text { attitude of } \\
\text { discoveries and } \\
\text { creativity }\end{array}$ & 80.36 & Good & 80 & Good & 85.71 & Good \\
\hline 5 & $\begin{array}{l}\text { open thinking } \\
\text { and cooperation }\end{array}$ & 84.53 & Good & 83.54 & Good & 83.93 & Good \\
\hline 6 & Persistence & 83.33 & Good & 80.83 & Good & 86.31 & Very Good \\
\hline 7 & $\begin{array}{l}\text { sensitive to the } \\
\text { surrounding } \\
\text { environment }\end{array}$ & 84.82 & Good & 82.19 & Good & 83.93 & Good \\
\hline & Avarage & 81.76 & Good & 82.89 & Good & 86.44 & Very Good \\
\hline
\end{tabular}

\section{Conclusion}

The use of models of problem-based learning assisted exe-learning may enhance the learning outcome of students in the groups of middle and high academic ability related to comprehension of the concept and characteristics of wave mechanics, as well as improving the student's scientific attitude 
Acknowledgements. The 4th International Conference on Education In Muslim Society (ICEMS) 2018. UIN Syarif Hidayatullah Jakarta.

\section{References}

[1] A. Tongchai, M. D. Sharma, I. D. Johnston, K. Arayathanitkul, and C. Soankwan, "Developing, evaluating and demonstrating the use of a conceptual survey in mechanical waves," Int. J. Sci. Educ., vol. 31, no. 18, pp. 2437-2457, 2009.

[2] P. Barniol and G. Zavala, "The mechanical waves conceptual survey: An analysis of university students' performance, and recommendations for instruction," Eurasia J. Math. Sci. Technol. Educ., vol. 13, no. 3, pp. 929-952, 2017.

[3] M. C. Wittmann, R. N. Steinberg, and E. F. Redish, "Making Sense of How Students Make Sense of Mechanical Waves," Phys. Teach., vol. 37, no. January, p. 15, 1999.

[4] S. Leccia, A. Colantonio, E. Puddu, S. Galano, and I. Testa, "Teaching about mechanical waves and sound with a tuning fork and the Sun," Phys. Educ., vol. 50, no. 6, pp. 677-689, 2015.

[5] A. A. Silva, "Determining the speed of sound in the air by sound wave interference," Eur. J. Phys., vol. 38, no. 4, 2017.

[6] L. F. Henderson, M. Jia-Huan, S. Akira, and T. Kazuyoshi, "Refraction of a shock wave at an air-water interface," Fluid Dyn. Res., vol. 5, no. 5-6, pp. 337-350, 1990.

[7] B. S. Ambrose, P. S. Shaffer, R. N. Steinberg, and L. C. McDermott, "An investigation of student understanding of single-slit diffraction and double-slit interference," Am. J. Phys., vol. 67, no. 2, pp. 146-155, 1999.

[8] M. C. Wittmann and E. Chase, "Evidence of embodied cognition about wave propagation," AIP Conf. Proc., vol. 1413, pp. 383-386, 2012.

[9] A. Rahma, J. Festiyed, and L. Dwiridal, "PENERAPAN MODEL PROBLEM BASED LEARNING DENGAN PENILAIAN AUTENTIK PADA MATERI GETARAN , GELOMBANG , BUNYI , DAN CAHAYA TERHADAP KOMPETENSI IPA PESERTA DIDIK KELAS VIII SMP NEGERI 4 KUBUNG Mahasiswa Pendidikan Fisika , FMIPA Universitas Negeri Padang Staf P,” vol. 6 , no. 2014, pp. 1-8, 2015.

[10] M. A. S, M. Ali, and M. Pasaribu, "Pengaruh Model Pembelajaran Berbasis Masalah terhadap Hasil Belajar Fisika Pada Siswa Kelas XI SMA Negeri 5 Palu," J. Pendidik. Fis. Tadulako Univ. Tadaluko Palu, vol. 1, no. 2, pp. 39-43, 2013.

[11] R. A. Tarmizi and S. Bayat, "Effects of problem-based learning approach in learning of statistics among university students," Procedia - Soc. Behav. Sci., vol. 8, no. 5, pp. 384-392, 2010.

[12] R. R. Sihaloho, S. Sahyar, and E. M. Ginting, "The Effect of Problem Based Learning (PBL) Model toward Student's Creative Thinking and Problem Solving Ability in Senior High School," IOSR J. Res. Method Educ., vol. 07, no. 04, pp. 11-18, 2017.

[13] H. S. Barrows, N. Tamblyn, and S. Jonas, "Problem-Based Learning Preface," Probl. Learn. An Approach to Med. Educ., 1980.

[14] A. S. Argaw, B. B. Haile, B. T. Ayalew, and S. G. Kuma, "The effect of problem based learning (PBL) instruction on students' motivation and problem solving skills of physics," Eurasia J. Math. Sci. Technol. Educ., vol. 13, no. 3, pp. 857-871, 2017.

[15] B. J. Duch, "duct barbara," Probl. Learn. Phys. Power Students Teach. Students. J. Coll. Sci. Teach., vol. 15, no. (5), p. 20, 1996.

[16] K. Agustina, W. H. Kristiyanto, and D. Noviandini, "International Journal of Active Learning Learning Design of Problem Based Learning Model Based on Recommendations of Sintax Study and Contents Issues on Physics Impulse Materials with Experimental Activities," vol. 2, no. 2, pp. 68-81, 2017.

[17] O. Ojaleye, A. O. A. Awofala, and A. O. A. Blended, "Blended Learning and Problem-Based 
Learning Instructional Strategies as Determinants of Senior Secondary School Students 'Achievement in Algebra To cite this article: Blended Learning and Problem-Based Learning Instructional Strategies as Determinants o," 2018.

[18] M. Rubiah, "Implementation of Problem Based Learning Model in Concept Learning Mushroom as a Result of Student Learning Improvement Efforts Guidelines for Teachers," vol. 7, no. 22, pp. 26-30, 2016.

[19] B. Journal, E. Vol, E. Centre, and D. Uk, "The Effectiveness Of Problem Based Learning Strategy In The Acquisition Of Scientific Concepts In Physics And The Development Of Science Operations Among The Ninth Grade Female Students.," Br. J. Educ., vol. 5, no. 2, pp. 1-9, 2017.

[20] M. F. Goes, M. A. Sinhoreti, S. Consani, and M. A. Silva, "Morphological effect of the type, concentration and etching time of acid solutions on enamel and dentin surfaces.," Braz. Dent. J., vol. 9, no. 1, pp. 3-10, 1998.

[21] H. Shafqat, A. Tayyab, A. B. Muqsud, A. Sarfaraz, and A. Nasir, "The Effectiveness of scientific attitude toward Physics teaching through Inquiry Method Verses Traditional Teaching Lecture Method of female students at Secondary School Level in Pakistan," Interdiscip. J. Contemp. Res. Bus., vol. 3, no. 4, pp. 441-446, 2011.

[22] D. M. Kaufman and K. V. Mann, "Basic sciences in problem-based learning and conventional curricula: Students' attitudes,” Med. Educ., vol. 31, no. 3, pp. 177-180, 1997.

[23] S. Nurdin and W. Setiawan, "Improving Students ' Cognitive Abilities And Creative Thinking Skills On Temperature And Heat Concepts Through An Exelearning-Assisted Problem Based Learning," Int. J. Sci. Technol. Res., vol. 5, no. 12, pp. 59-63, 2016.

[24] D. Vlachopoulos and A. Makri, The effect of games and simulations on higher education: a systematic literature review, vol. 14, no. 1. 2017.

[25] C. O. Rodríguez, E. M. M. Morgado, and D. F. G. da, "The eXeLearning and GeoGebra integration for teaching geometrics definitions and vectors representations through learning objects," Proc. Second Int. Conf. Technol. Ecosyst. Enhancing Multicult. - TEEM '14, pp. 639-645, 2014.

[26] E. M. Mussoi, "GeoGebra and eXe Learning: applicability in the teaching of Physics and Mathematics," Syst. Cybern. Informatics, vol. 9, no. 2, pp. 61-66, 2011.

[27] P. A. Tias, S. Istamar, and A. D. Corebima, "The contribution of intelligence quotient ( IQ ) on biology academic achievement of senior high school students in Medan , Indonesia," Int. J. Educ. Policy Res. Rev., vol. 2, no. 10, pp. 141-147, 2015.

[28] P. Checa and P. Fernández-Berrocal, "The role of intelligence quotient and emotional intelligence in cognitive control processes," Front. Psychol., vol. 6, no. DEC, 2015.

[29] S. C. Moscosoa, S. S. Chaves, M. P. Vidal, and M. Teresa Anguera Argilaga, "Reporting a program evaluation: Needs, program plan, intervention, and decisions," Int. J. Clin. Heal. Psychol., vol. 13, no. 1, pp. 58-66, 2013.

[30] A. Harris et al., "The Use and interpreatation of Quasi-Experimental Studies in Medical Informatics," J Am Med Inf. Assoc., vol. 13, no. 1, pp. 16-23, 2006.

[31] H. Taherdoost, "Sampling Methods in Research Methodology; How to Choose a Sampling Technique for Research," SSRN Electron. J., vol. 5, no. 2, pp. 18-27, 2016.

[32] G. Sharma, “Impact Factor: 5.2 IJAR,” Int. J. Appl. Res., vol. 3, no. 7, pp. 749-752, 2017.

[33] V. P. Coletta and J. A. Phillips, "Interpreting FCI scores: Normalized gain, preinstruction scores, and scientific reasoning ability," Am. J. Phys., vol. 73, no. 12, pp. 1172-1182, 2005.

[34] R. R. Hake, "Interactive-engagement versus traditional methods: A six-thousand-student survey of mechanics test data for introductory physics courses," Am. J. Phys., vol. 66, no. 1, pp. 64-74, 1998.

[35] H. Riyadi and M. Wati, "Pengembangan Alat Peraga Fisika Materi Cahaya untuk Melatihkan Keterampilan Proses Sains Siswa SMP,” J. Ilm. Pendidik. Fis., vol. 2, no. 1, pp. 42-55, 2018.

[36] N. Purwanto, Prinsip-prinsip dan Teknik Evaluasi Pengajaran. Bandung: PT Remaja Rosdakarya, 2006.

[37] T. H. E. Effect, O. F. Health, E. On, P. Hygiene, B. In, and P. Vaginal, "Leadership and 
Cooperative Learning and Its Relation Towards Students' Grade Achievement In ProblemBased Learning Environment," Int. Conf. Appl. Sci. Heal., pp. 292-296, 2017.

[38] M. Uli, O. Siboro, S. Tarigan, and R. D. Suyanti, "The Effect Of Learning Model Using ExeLearning Media And Learning Motivation To Chemistry Learning Outcomes On Students SMAN 1 Batang Kuis," IOSR J. Res. Method Educ., vol. 7, no. 5, pp. 13-17, 2017

[39] M. Demirel, "Effects of Problem-Based Learning on Attitude: A Meta-analysis Stud," EURASIA J. Math. Sci. Technol. Educ., vol. 12, no. 8, pp. 2115-2137, 2016. 